\title{
Crime and economic conditions in Malaysia
}

\begin{abstract}
Purpose: The purpose of this paper is to analyze the impact of economic conditions on various categories of criminal activities in Malaysia for the period 1973-2003.

Design/methodology/approach: The autoregressive distributed lag bounds testing procedure was employed as the main tool. Dynamic ordinary least squares was also used to check the robustness of the results.

Findings: The results indicate that murder, armed robbery, rape, assault, daylight burglary, and motorcycle theft exhibit long-run relationships with economic conditions, and the causal effect in all cases runs from economic conditions to crime rates and not vice versa. In the long-run, strong economic performances have a positive impact on murder, rape, assault, daylight burglary, and motorcycle theft, while on the other hand, economic conditions have negative impact on armed robbery.

Research limitations/implications: Further researches using other macroeconomic variables and also other countries are encouraged.

Practical implications: The important implication of this result is that real gross national product per capita is an exogenous variable and it is, therefore, useful for fiscal policy variable. Government of the day should seriously consider the results of this study in any crimefighting policies that are formulated.

Originality/value: An economic viewpoint of criminal activities in Malaysia.
\end{abstract}

Keyword: Crimes; Economic conditions; Malaysia 